\title{
Perubahan Waktu Reaksi terhadap Stimulus Visual pada PPDS Anestesiologi dan Terapi Intensif RSUP Dr. Hasan Sadikin Bandung setelah Bertugas Selama 24 Jam
}

\author{
Lukman Hidayat, Iwan Abdul Rachman, Iwan Fuadi \\ Departemen Anestesiologi dan Terapi Intensif \\ Fakultas Kedokteran Universitas Padjadjaran/RSUP Dr. Hasan Sadikin Bandung
}

\begin{abstract}
Abstrak
Waktu reaksi dibutuhkan oleh dokter anestesi karena harus berpikir dan bertindak cepat serta tepat dalam situasi kritis mengancam jiwa pasien. Jaga malam selama 24 jam dapat meyebabkan kelelahan dan gangguan tidur sehingga waktu reaksi menjadi lebih lambat. Tujuan penelitian ini mengetahui perubahan waktu reaksi terhadap stimulus visual pada PPDS Anestesiologi dan Terapi Intensif FK Unpad setelah bertugas selama 24 jam di RSUP Dr. Hasan Sadikin Bandung. Penelitian ini berlangsung pada bulan Oktober-November 2019 merupakan pretest and posttest control group design dilakukan pada 58 peserta dengan menilai waktu reaksi sebelum bertugas dan setelah bertugas selama 24 jam diperiksa menggunakan metode Ruler Drop. Analisis data menggunakan Uji Wilcoxon karena data distribusi tidak normal berdasar atas hasil Uji Kolgomorov Smirnov. Pada penelitian ini diperoleh median waktu reaksi setelah bertugas selama 24 jam menjadi lebih lama dibanding dengan sebelum bertugas. Nilai median waktu reaksi sebelum bertugas adalah 0,20 detik (range 0,10-0,25 detik), sedangkan waktu reaksi setelah bertugas selama 24 jam adalah 0,23 detik (range 0,17-0,32 detik), dengan rerata lama jam tidur selama bertugas 24 jam adalah 2,32 $\pm 1,552$ jam. Simpulan, waktu reaksi lebih lama pada peserta PPDS Anestesiologi dan Terapi Intensif FK UNPAD setelah bertugas selama 24 jam.
\end{abstract}

Kata kunci: Fungsi kognitif, gangguan tidur, kelelahan, metode ruler drop, waktu reaksi

\section{Change in Visual Stimulus Reaction Time of Anesthesiology and Intensive Care Residents after a 24-Hour Shift}

\begin{abstract}
A good reaction time is crucial for anesthesiologists when doing their work because their quick thinking and action are critical in life-threatening situations. A 24-hour shift may cause fatigue and sleep disturbances, lowering cognitive function and reaction time necessary for patient care. This study aimed to assess changes in the visual reaction time of the Anesthesiology and Intensive Care resident doctors FK Unpad after 24hour shift in Dr. Hasan Sadikin General Hospital Bandung, Indonesia. This pretest and posttest control study was performed July-October 2019 on 58 subjects by evaluating the reaction time before and after a 24-hour shift using the 'ruler drop' method. Data were analyzed with Wilcoxon test after data were proven to be non-normally distributed based on the results of the Kolgomorov Smirnov test. The median visual reaction time after a 24-hour shift was observed to be slower that before the shift, with 0.20 seconds reaction time before the shift (range $0.10-0.25$ seconds) and 0.23 seconds after the shift (range $0.17-0.32$ seconds). The average sleep time among the residents who work in the 24-hour shift was $2.32 \pm 1,552$ hours. Hence, the visual reaction time is slower after 24-hour shift among residents of Anesthesiology and Intensive Care
\end{abstract}

Key words: Cognitive function, fatigue, sleep disturbance, reaction time, ruler drop method

Korespondensi: Lukman Hidayat, dr, Departemen Anestesiologi dan Terapi Intensif Fakultas Kedokteran Universitas Padjadjaran/Rumah Sakit Umum Pusat Dr. Hasan Sadikin Bandung, Jl. Pasteur No. 38 Bandung 40274, Tlpn 0222038285,Email: mamentshow@gmail.com 


\section{Pendahuluan}

Waktu reaksi yang cepat penting bagi seorang dokter anestesi dalam melakukan pelayanan kepada pasien.Seorang dokter anestesi tidak boleh melakukan kesalahan dan harus segera memahami serta melakukan koreksi bila melakukan kesalahan. Seorang dokter anestesi harus mengetahui data medis pasien yang cukup, menyusun perencanaan anestesi yang baik, melakukan monitoring kondisi pasien secara intensif, dan mengambil keputusan yang cepat tepat untuk mendapatkan hasil luaran pasien yang baik. Kegiatan tersebut membutuhkan waktu reaksi yang cepat, kewaspadaan yang tinggi, dan kesigapan yang membutuhkan energi yang besar sehingga dapat menimbulkan kelelahan dan stres fisik dan mental bagi seorang dokter anestesi. ${ }^{1,2}$

Kelelahan di kalangan tenaga kesehatan mempunyai kaitan erat dengan angka kejadian kesalahan dalam tindakan medis yang memengaruhi luaran pasien. Kelelahan itu adalah kondisi fisik dan mental yang menurun sehingga mengurangi kapasitas, efisiensi, dan efektivitas seseorang dalam bekerja. Pada kalangan tenaga kesehatan, dokter anestesi lebih rentan mengalami kelelahan dibanding dengan dokter spesialis lain. Angka kejadian kelelahan dokter anestesi di Eropa dan Amerika berkisar 17-84\%. Penyebab utama kelelahan pada dokter anestesi adalah jaga malam yang dapat menyebabkan gangguan tidur. $^{2,3}$

Gangguan tidur terjadi disebabkan oleh ketidakseimbangan kebutuhan tidur dengan kualitas dan kuantitas tidur. Kebutuhan tidur seseorang dalam satu hari sekitar 7-9 jam. Pada penelitian di India tahun 2016, 22 orang yang hanya tidur 3 jam sebelum bekerja mengalami gangguan fungsi kognitif dan waktu reaksi menjadi lebih lambat dibanding dengan kelompok yang tidur selama 8 jam sebelum bekerja. Salah satu penyebab gangguan tidur di kalangan tenaga kesehatan adalah jaga malam (night shift). Tenaga kesehatan yang melakukan jaga malam lebih dari 12 jam dapat meningkatkan kejadian kesalahan di dalam tindakan medis dua kali lipat dibanding dengan tenaga kesehatan yang melakukan jaga malam selama 8 jam. Sleep deprivation menyebabkan peningkatan aktivitas saraf simpatis yang akan menstimulasi peningkatan hormon kortisol dan interleukin 6 (IL-6) di dalam darah dan otak terutama di bagian prefrontal cortex. Hormon kortisol dan mediator inflamasi IL-6 akan menghambat mediator orexyn yang akan menurunkan konsentrasi dan fungsi kognitif seseorang. ${ }^{3-5}$

Kelelahan berkaitan dengan gangguan tidur dapat menyebabkan penurunan fungsi kognitif dan psikomotor, waktu reaksi menjadi lebih lambat, penurunan dalam memutuskan keputusan yang penting untuk kepentingan pasien, risiko ganggguan kesehatan seperti infeksi, ulkus peptikum, hipertensi dan serangan jantung, serta gangguan depresi dan kecemasan. Seorang residen atau dokter anestesi yang menjalani jaga malam akan mengalami gangguan tidur secara akut dan kronik serta gangguan siklus sirkadian yang dapat mengganggu kemampuan psikomotor. Keadaan ini dapat dilihat pada penelitian di Inggris yang melibatkan residen anestesi yang melakukan jaga selama 24 jam, fungsi psikomotor residen tersebut menurun dalam monitoring pasien selama anestesi, dan waktu yang dibutuhkan oleh residen anestesi untuk melakukan tindakan intubasi menjadi lebih lama sekitar 34\% dibanding dengan residen yang melakukan pelayanan di siang hari. Pada penelitian di India, seorang dokter anestesi yang terjaga selama menjalani jaga selama 24 jam memiliki penurunan kinerja medis hampir sama dengan kandungan 0,1\% alkohol di dalam darah seseorang. Jaga malam yang melebihi 24 jam dapat juga meningkatkan kesalahan dua kali lipat dalam melakukan tindakan medis, akibat penurunan kemampuan kognitif dan waktu reaksi. ${ }^{3-6}$

Waktu reaksi adalah interval waktu yang dibutuhkan antara pemberian stimulus dan aksi terhadap stimulus yang diberikan. Waktu reaksi dapat dijadikan sebagai alat ukur fungsi asosiasi sensorimotor dan kinerja individu. Hal ini melibatkan proses stimulus, pengambilan keputusan, dan respons dalam menanggapi stimulus. Waktu reaksi ini dapat dijadikan 
indikator kinerja residen dalam menghadapi suatu pengambilan keputusan medis yang penting bagi pasien. Pada penelitian lain di India tahun 2016, waktu reaksi 30 orang residen penyakit dalam dan bedah umum setelah bertugas selama 24 jam menjadi lebih lambat dibanding dengan sebelum jaga malam. Hasil penelitian ini memiliki hasil yang sama dengan penelitian di Amerika Serikat tahun 2016 terhadap 21 orang dokter anestesi yang melakukan tugas jaga selama 17 jam on call di rumah. Waktu reaksi setelah melaksanakan tugas jaga selama 17 jam on call menjadi lebih lambat dibanding dengan waktu reaksi bila dokter anestesi bekerja sehari hari tanpa on call selama 17 jam. ${ }^{5-8}$

Tujuan penelitian ini adalah mengetahui perubahan waktu reaksi dengan stimulus secara visual pada peserta PPDS anestesi dan terapi intensif setelah bertugas selama 24 jam di Rumah Sakit Dr. Hasan Sadikin Bandung.

\section{Subjek dan Metode}

Penelitian ini menggunakan metode pretest and posttest control design. Penelitian dilakukan di Departemen Anestesiologi dan Terapi Intensif RSUP Dr. Hasan Sadikin, pada bulan November 2019 setelah mendapatkan persetujuan dari Komisi Etik Penelitian Kesehatan RSUP Dr. Hasan Sadikin Bandung Nomor LB.02.01/X.6.5/216/2019.

Subjek penelitian adalah Peserta Program Pendidikan Spesialis (PPDS) Anestesiologi dan Terapi Intensif FK Universitas Padjadjaran, RSUP Dr. Hasan Sadikin Bandung. Pemilihan subjek penelitian ini berdasar atas kriteria inklusi adalah peserta PPDS Anestesiologi dan Terapi Intensif yang aktif dan bertugas selama 24 jam di RSUP Dr. Hasan Sadikin Bandung dan kriteria eksklusi adalah peserta penelitian mengonsumsi obat tidur, obat anticemas, atau antidepresi dalam 24 jam sebelum dilakukan pemeriksaan pertama dan selama bertugas 24 jam, jumlah lama tidur peserta PPDS Anestesiologi dan Terapi Intensif sebelum bertugas $\leq 3$ jam, dan jumlah lama tidur peserta PPDS Anestesiologi dan Terapi Intensif selama bertugas $\geq 6$ jam. Penentuan jumlah sampel menggunakan formula perhitungan besar sampel pada penelitian komparatif numerik berpasangan dengan taraf kepercayaan 95\%, kuasa uji (power test) 95\%, dan didapatkan jumlah sampel minimal 49 orang. Pengambilan sampel dilakukan secara purposive sampling.

Peralatan yang digunakan dalam penelitian ini meliputi penggaris sepanjang $60 \mathrm{~cm}$, alat tulis, dan tabel konversi panjang penggaris menjadi waktu reaksi. Peserta penelitian diberikan penjelasan tentang hal prosedur pemeriksaan waktu reaksi secara visual dengan mempergunakan ruler drop method sebelum bertugas selama 24 jam. Waktu reaksi dinyatakan dalam satuan detik dan diperiksa sebanyak 2 kali, yaitu sebelum bertugas dan setelah bertugas 24 jam. Tata cara pengukuran, yaitu peserta menangkap penggaris menggunakan ibu jari dan jari telunjuk yang memiliki jarak $2 \mathrm{~cm}$ dari tangan peserta yang dominan, penggaris dengan panjang $60 \mathrm{~cm}$ diletakkan secara vertikal dengan jari telunjuk dan ibu jari berada di $0 \mathrm{~cm}$. Penggaris dijatuhkan tanpa memberikan abaaba. Peserta menangkap penggaris tersebut dengan ibu jari dan telunjuk dan jarak dalam $\mathrm{cm}$ di atas jari telunjuk peserta penelitian dicatat. Peserta mengulang prosedur ini sebanyak 3 kali.

Uji statistik menggunakan Kolmogorovsmirnov $(n>50)$ untuk menguji data yang berdistribusi normal atau tidak. Apabila data berdistribusi normal menggunakan uji $\mathrm{t}$ berpasangan untuk membandingkan variabel numerik antara 2 kelompok berpasangan. Bila data tidak berdistribusi normal menggunakan Uji Wilcoxon. Data hasil penelitian dicatat dan diolah menggunakan program statistical product and service solution (SPSS) versi 24.0 for windows.

\section{Hasil}

Penelitian ini dilaksanakan pada kelompok berpasangan dengan melakukan pengukuran waktu reaksi sebelum dan setelah bertugas selama 24 jam sehingga karakteristik subjek penelitian berdasar atas jenis kelamin, usia, jumlah lama tidur sebelum bertugas 24 jam, 
Tabel 1 Karakteristik Subjek Penelitian

\begin{tabular}{lc}
\hline \multicolumn{1}{c}{ Variabel } & $\mathbf{n = 5 8}$ \\
\hline Jenis kelamin, $\mathrm{n}(\%)$ & $42(72 \%)$ \\
Laki-laki & $16(28 \%)$ \\
Perempuan & \\
Usia (tahun) & $26,00-39,00$ \\
$\quad$ Range (min.-maks.) & $32,09 \pm 3,321$ \\
Mean \pm Std & \\
Lama tidur sebelum bertugas 24 & \\
jam (jam) & $4,00-8,50$ \\
Range (min.-maks.) & $5,793 \pm 1,174$ \\
Mean \pm Std & \\
Lama tidur saat bertugas 24 jam & \\
(jam) & $0,00-5,00$ \\
Range (min.-maks.) & $2,32 \pm 1,552$ \\
Mean \pm Std & \\
Tingkat komptensi PPDS, n (\%) & $33(57 \%)$ \\
Tingkat 1(semester 1-4) & $9(15 \%)$ \\
Tingkat 2 (semester 5-6) & $16(28 \%)$ \\
Tingkat 3 (semester $\geq 7)$ & \\
Konsumsi kafein, n (\%) & $21(36 \%)$ \\
Ya & $37(64 \%)$ \\
Tidak & $45(78 \%)$ \\
Status menikah, n (\%) & $13(22 \%)$ \\
Ya & \\
Tidak & \\
Ya & \\
Tidak & \\
\hline & \\
\hline &
\end{tabular}

jumlah lama tidur selama bertugas 24 jam, tingkat kompetensi PPDS, status menikah, dan status memiliki anak dipastikan homogen (Tabel 1).

Rerata waktu reaksi setelah bertugas selama 24 jam berdasar atas karakteristik peserta penelitian, yaitu jenis kelamin, tingkat kompetensi PPDS, status menikah, dan status memiliki anak menjadi lebih lambat dibanding dengan sebelum bertugas. Pada penelitian ini setiap kelompok karakteristik tidak dapat dilakukan perbandingan secara statistik karena jumlah peserta penelitian yang tidak seimbang setiap kelompok (Tabel 2).

Data hasil waktu reaksi sebelum dan setelah bertugas selama 24 jam berdasar atas hasi Uji Kolgomorov Smirnov memiliki distribusi tidak normal sehingga waktu reaksi dinyatakan dalam bentuk median dan range. Hasil pemeriksaan waktu reaksi dengan menggunakan teknik ruler drop method didapatkan median waktu reaksi setelah bertugas selama 24 jam lebih lambat $(0,23$ detik) dibanding dengan sebelum bertugas selama 24 jam( 0,20 detik) dan berdasar atas Uji Wilcoxon didapatkan bahwa perbedaan tersebut bermakna $(\mathrm{p}<0,005$; Tabel 3$)$.

Tabel 2 Waktu Reaksi berdasar atas Karakteristik Subjek Penelitian

\begin{tabular}{|c|c|c|}
\hline \multirow{2}{*}{ Variabel } & \multicolumn{2}{|c|}{ Mean $\pm S D$ Waktu Reaksi (detik) } \\
\hline & Sebelum Bertugas & Setelah Betugas \\
\hline \multicolumn{3}{|l|}{ Jenis kelamin } \\
\hline Laki-laki ( $\mathrm{n}=42$ orang) & $0,19 \pm 0,029$ & $0,22 \pm 0,025$ \\
\hline Perempuan ( $\mathrm{n}=16$ orang) & $0,20 \pm 0,022$ & $0,23 \pm 0,023$ \\
\hline \multicolumn{3}{|l|}{ Tingkat kompetensi PPDS } \\
\hline Tingkat 1 (n=33 orang) & $0,19 \pm 0,031$ & $0,23 \pm 0,026$ \\
\hline Tingkat 2 ( $\mathrm{n}=9$ orang) & $0,20 \pm 0,014$ & $0,23 \pm 0,018$ \\
\hline Tingkat 3 ( $\mathrm{n}=16$ orang) & $0,19 \pm 0,023$ & $0,22 \pm 0,026$ \\
\hline \multicolumn{3}{|l|}{ Konsumsi kafein } \\
\hline Konsumsi (n=21 orang) & $0,20 \pm 0,018$ & $0,23 \pm 0,019$ \\
\hline Tidak konsumsi (n=37 orang) & $0,19 \pm 0,030$ & $0,23 \pm 0,028$ \\
\hline \multicolumn{3}{|l|}{ Status menikah } \\
\hline Menikah ( $\mathrm{n}=45$ orang) & $0,20 \pm 0,028$ & $0,23 \pm 0,025$ \\
\hline Belum ( $\mathrm{n}=13$ orang) & $0,20 \pm 0,023$ & $0,22 \pm 0,026$ \\
\hline \multicolumn{3}{|l|}{ Status memiliki anak } \\
\hline Memiliki anak ( $\mathrm{n}=40$ orang) & $0,19 \pm 0,029$ & $0,22 \pm 0,021$ \\
\hline Belum ( $\mathrm{n}=18$ orang) & $0,20 \pm 0,022$ & $0,23 \pm 0,031$ \\
\hline
\end{tabular}


Tabel 3 Perbandingan Waktu Reaksi

\begin{tabular}{lccc}
\hline & \multicolumn{2}{c}{ Kelompok } & \\
\cline { 2 - 3 } $\begin{array}{l}\text { Waktu } \\
\text { Reaksi } \\
\text { (detik) }\end{array}$ & $\begin{array}{c}\text { Sebelum } \\
\text { Bertugas } \\
\text { Selama } \\
\text { 24 Jam } \\
\text { (n=58) }\end{array}$ & $\begin{array}{c}\text { Setelah } \\
\text { Bertugas } \\
\text { Selama } \\
\text { 24 Jam } \\
\mathbf{( n = 5 8 )}\end{array}$ & Nilai P \\
\hline Median & 0,20 & 0,23 & \\
$\begin{array}{l}\text { Range } \\
\text { (min.- } \\
\text { maks.) }\end{array}$ & $0,10-0,25$ & $0,17-0,32$ & $0,0001^{* *}$ \\
\hline
\end{tabular}

Keterangan: untuk data numerik nilai p diuji dengan uji T berpasangan apabila data berdsitribusi normal dengan alternatif Uji Wilcoxon apabila data tidak berdistribusi normal. Nilai kemaknaan berdasar atas nilai $\mathrm{p}<0,05$. Tanda* menunjukkan nilai $\mathrm{p}<0,05$ artinya signifkan atau bermakna secara statistik

\section{Pembahasan}

Waktu reaksi pada penelitian ini dinilai secara visual karena jaras stimulus secara visual lebih kompleks, melibatkan proses kimia yang lebih rumit, dan jaras saraf visual lebih banyak kolateral dibanding dengan audio. Nilai rerata waktu reaksi yang dinilai secara visual pada orang yang tidak mengalami kelelahan dan gangguan tidur adalah $0,18-0,2$ detik, sedangkan waktu reaksi yang dinilai secara audio memiliki nilai rerata $0,14-0,16$ detik. Waktu reaksi dapat dipengaruhi oleh beberapa faktor seperti jenis kelamin, usia, konsumsi obat obatan seperti kafein, status menikah, dan status memiliki anak. ${ }^{3-6}$

Peserta penelitian ini memiliki rentang usia 26-39 tahun. Penelitian ini tidak dilakukan analisis korelasi antara usia dan waktu reaksi karena metodologi yang tidak mendukung. Penelitian di Uganda yang menyatakan usia muda memiliki waktu reaksi dan fungsi kognitif yang lebih baik dibanding dengan usia tua. Waktu reaksi menjadi lambat seiring usia yang bertambah, waktu reaksi menurun pada usia $\geq 50$ tahun karena penurunan fungsi kognitif yang menurunkan kecepatan sinyal impuls oleh sistem saraf. ${ }^{9,10}$

Lama tidur rerata sebelum bertugas pada subjek penelitian adalah 5,79 $\pm 1,174$ jam.
Sementara itu, untuk rerata lama tidur saat bertugas adalah 2,32 $\pm 1,552$ jam. Menurut teori, lama tidur yang cukup pada dewasa muda sekitar 6-8 jam dalam sehari. Pada penelitian di India tahun 2016, terdapat 22 orang dengan lama tidur $\leq 3$ jam sebelum bekerja di malam hari yang mengalami gangguan fungsi kognitif dan waktu reaksi menjadi lebih lambat bila dibanding dengan kelompok yang tidur selama 8 jam. Jumlah tidur yang berkurang dapat menyebabkan gangguan tidur kronis sehingga menyebabkan gangguan fungsi kognitif. Menurut data yang diperoleh, subjek penelitian sebelum memulai sif 24 jam keesokan harinya, secara kuantitas tidur dapat dikategorikan tidak normal, dengan rerata lama waktu tidur kurang dari 6 jam. Kekurangan waktu tidur selama 2-4 jam secara kumulatif setiap harinya dapat memicu gangguan fungsi kognitif dan menurunkan kinerja dan konsentrasi seseorang dalam bekerja dan melakukan pelayanan kesehatan kepada pasien. ${ }^{4,8-12}$

Lama tidur subjek penelitian yang menjalani sif 24 jam rerata adalah dua jam. Penelitian sebelumnya di Inggris menunjukkan bahwa seseorang yang terjaga selama 17-19 jam menunjukkan penurunan kinerja dan kewaspadaan. Kondisi tersebut sebanding dengan seseorang yang mabuk minuman beralkohol. Penelitian lain menunjukkan seseorang yang tidur $\leq 6$ jam menunjukkan penurunan kemampuan reaksi, kecepatan pengambilan keputusan, serta daya ingat kata, dan angka. ${ }^{7-11}$

Jumlah subjek yang mengikuti penelitian ini sebanyak 58 orang. Berdasar atas jenis kelamin, 42 orang laki-laki (72\%) dan 16 orang perempuan (28\%). Waktu reaksi rerata sebelum bertugas selama 24 jam pada kelompok laki-laki adalah 0,19 $\pm 0,029$ detik, sedangkan setelah bertugas 24 jam pada kelompok laki-laki adalah $0,22 \pm 0,025$ detik. Kelompok perempuan memiliki nilai rerata waktu reaksi sebelum bertugas selama 24 jam adalah 0,20 0,022 detik, sedangkan setelah bertugas selama 24 jam adalah $0,23 \pm 0,023$ detik. Pada penelitian di India tahun 2010 terhadap tenaga kesehatan, waktu reaksi 
antara kelompok laki-laki dan perempuan tidak berbeda secara signifikan setelah jaga malam selama 24 jam. ${ }^{7,13-15}$

Penelitian lain di India, waktu reaksi pada perempuan lebih lama dibanding dengan laki-laki karena pengaruh kadar steroid yang berubah pada wanita bergantung pada siklus menstruasi. Hormon steroid menyebabkan retensi natrium dan air. Kadar elektrolit natrium yang tinggi ini memengaruhi proses transmisi impuls di celah sinapsis sehingga memengaruhi kecepatan saraf sensorik dan motorik $^{7,13-15}$

Penilaian waktu reaksi berdasar atas tingkat kompetensi PPDS Anestesiologi dan Terapi Intensif didapatkan bahwa tingkat kompetensi 1 sebanyak 33 orang memiliki nilai rerata waktu reaksi sebelum bertugas selama 24 jam adalah 0,19 $\pm 0,031$ detik, sedangkan nilai rerata setelah bertugas selama 24 jam adalah $0,23 \pm 0,026$ detik. Peserta dengan tingkat kompetensi 2 sebanyak 9 orang memiliki nilai rerata waktu reaksi sebelum bertugas selama 24 jam adalah $0,20 \pm 0,014$ detik, sedangkan nilai rerata setelah bertugas selama 24 jam adalah $0,23 \pm 0,018$ detik. Peserta dengan tingkat kompetensi 3 sebanyak 16 orang memiliki nilai rerata waktu reaksi sebelum bertugas selama 24 jam adalah 0,19 $\pm 0,023$ detik sedangkan nilai rerata setelah bertugas selama 24 jam adalah 0,22 $\pm 0,026$ detik. Penelitian yang dilakukan di Bali pada tahun 2015, faktor tingkat kompetensi PPDS merupakan salah satu faktor yang akan menurunkan fungsi kognitif PPDS sehingga waktu reaksi menjadi lambat. Tingkat kompetensi PPDS yang lebih rendah memiliki beban kerja lebih banyak dan tingkat stres lebih tinggi pada saat jaga malam dibanding dengan tingkat kompetensi yang tinggi. Tingkat stres dan beban kerja dapat meningkatkan risiko kelelahan dan gangguan tidur sehingga menurunkan fungsi kognitif dan waktu reaksi menjadi lambat ${ }^{4,16}$

Penilaian waktu reaksi berdasar atas konsumsi kafein selama bertugas 24 jam didapatkan subjek yang konsumsi kafein sebanyak 21 orang nilai rerata waktu reaksi sebelum bertugas selama 24 jam adalah $0,20 \pm 0,018$ detik, sedangkan waktu reaksi setelah bertugas 24 jam adalah 0,23 $\pm 0,019$ detik. Pada kelompok yang tidak konsumsi kafein sebanyak 37 orang nilai rerata waktu reaksi sebelum bertugas selama 24 jam adalah $0,19 \pm 0,030$ detik, sedangkan waktu reaksi setelah bertugas 24 jam adalah $0,23 \pm 0,028$ detik. Hasil penelitian di Inggris pada tahun 2010 dinyatakan bahwa kafein dengan dosis 750-1500 mg selama bertugas membuat waktu reaksi menjadi lebih cepat., ${ }^{3,8}$

Penilaian waktu reaksi berdasar atas status menikah didapatkan bahwa pada kelompok dengan status menikah sebanyak 45 orang rerata waktu reaksi sebelum bertugas selama 24 jam adalah 0,20 $\pm 0,028$ detik, sedangkan waktu reaksi setelah bertugas 24 jam adalah $0,23 \pm 0,025$ detik. Pada kelompok yang belum menikah sebanyak 13 orang rerata waktu reaksi sebelum bertugas selama 24 jam adalah $0,20 \pm 0,023$ detik, sedangkan waktu reaksi setelah bertugas 24 jam adalah 0,22 $\pm 0,026$ detik. Pada penelitian di Uganda dijelaskan status menikah memiliki pengaruh terhadap perubahan waktu reaksi. Waktu reaksi pada kelompok yang belum menikah lebih cepat dibanding dengan kelompok menikah. Faktor stres pada kelompok menikah akan menurunkan fungsi kognitif seseorang. Penurunan fungsi kognitif memengaruhi proses penghantaran sinyal impuls pada sistem saraf menjadi lebih lambat sehingga waktu reaksi menjadi lebih lambat. Hasil penelitian di Uganda memiliki hasil yang berbeda dengan penelitian di Bali, yaitu status menikah tidak memiliki pengaruh signifikan terhadap penurunan fungsi kognitif yang dapat menyebabkan waktu reaksi menjadi lebih lama. $4,9,16$

Penilaian waktu reaksi berdasar atas status memiliki anak didapatkan bahwa pada kelompok dengan status memiliki anak sebanyak 40 orang rerata waktu reaksi sebelum bertugas selama 24 jam adalah $0,19 \pm 0,029$ detik, sedangkan waktu reaksi setelah bertugas 24 jam adalah $0,22 \pm 0,021$ detik. Pada kelompok yang belum memiliki anak sebanyak 18 orang rerata waktu reaksi sebelum bertugas selama 24 jam adalah $0,20 \pm 0,022$ detik, sedangkan waktu reaksi 
setelah bertugas 24 jam adalah $0,23 \pm 0,031$ detik. Pada penelitian di Uganda dijelaskan status memiliki anak memiliki pengaruh terhadap perubahan waktu reaksi. Waktu reaksi pada kelompok belum memiliki anak lebih cepat dibanding dengan kelompok yang sudah memiliki anak. Faktor stres pada kelompok memiliki anak menurunkan fungsi kognitif seseorang. Penurunan fungsi kognitif ini akan memengaruhi proses penghantaran sinyal impuls pada sistem saraf menjadi lebih lambat sehingga waktu reaksi menjadi lebih lambat. Hasil penelitian di Uganda memiliki hasil yang berbeda dengan penelitian di Bali, yaitu status menikah dan status memiliki anak tidak memiliki pengaruh yang signifikan terhadap penurunan fungsi kognitif yang dapat meyebabkan waktu reaksi menjadi lebih lama. ${ }^{4,9,16}$

Pada penelitian ini waktu reaksi pada 58 subjek setelah bertugas selama 24 jam menjadi lebih lambat dibanding dengan sebelum bertugas secara signifikan. Hasil untuk median waktu reaksi sebelum bertugas selama 24 jam adalah 0,20 detik dan setelah bertugas memiliki median waktu reaksi adalah 0,23 detik. Waktu reaksi setelah bertugas selama 24 jam pada penelitian ini lebih lambat dalam millisecond dibanding dengan sebelum bertugas dan melebihi waktu reaksi yang normal $(0,18-0,20$ detik). Pemanjangan waktu reaksi dalam millisecond melebihi nilai normal dapat memberikan gambaran penurunan kewaspadaan, konsentrasi, perhatian, fungsi kognitif, koordinasi sistem neuromuskular dan performa kinerja motorik. Waktu reaksi yang lambat ini juga menggambarkan penurunan fungsi kewaspadaan dan kesigapan seseorang terhadap sesuatu yang tidak diharapkan dan berbahaya. Waktu reaksi ini penting bagi seorang dokter anestesi untuk melakukan pelayanan kepada pasien terutama pada saat kritis. ${ }^{3,6-8}$

Hasil penelitian ini sama seperti penelitian di India pada tahun 2004 terhadap 286 orang tenaga kesehatan yang menjalani jaga malam selama 8 jam dengan hasil waktu reaksi lebih lama dibanding dengan sebelum jaga malam. Pada penelitian lain di India tahun 2016 terhadap 30 orang residen penyakit dalam dan bedah umum didapat hasil waktu reaksi setelah jaga selama 24 menjadi lebih lambat dibanding dengan sebelum jaga malam. Hasil penelitian ini juga memiliki hasil yang sama dengan penelitian di Amerika Serikat terhadap 21 orang dokter anestesi yang melakukan tugas jaga on call di rumah selama 17 jam. Waktu reaksi setelah melaksanakan tugas jaga selama 17 jam on call menjadi lebih lambat dibanding dengan waktu reaksi bila dokter anestesi bekerja sehari hari tanpa on call selama 17 jam. $^{3-4,7-10}$

Waktu reaksi setelah bertugas selama 24 jam menjadi lebih lama dibanding dengan sebelum bertugas selama 24 jam mungkin disebabkan oleh gangguan kualitas dan kuantitas tidur peserta PPDS karena secara kuantitas tidur hanya rerata 2 jam. Jumlah tidur yang tidak cukup menyebabkan rasa mengantuk dan kelelahan yang dapat menurunkan fungsi kinerja otak bagian prefrontal cortex sehingga menurunkan fungsi kognitif, fungsi berpikir, konsentrasi, kreativitas, dan fungsi luhur lainnya. ${ }^{4,8-10}$

Kelelahan dan gangguan tidur akibat jaga malam dapat memicu perubahan neurotransmiter dan neuroinflamasi di otak. Proses neuroinflamasi dalam otak dipengaruhi oleh sistem imunitas dan disfungsi aksis hipotalamus - kelenjar pituitari - kelenjar adrenal (HPA). Gangguan tidur dapat meningkatkan respons saraf simpatis di dalam tubuh. Respons saraf simpatis yang tinggi akan meningkatkan jumlah hormon kortisol yang menembus sawar darah di otak melalui aksis HPA. Proses tersebut akan menurunkan jumlah melatonin di otak dan meningkatkan mediator inflamasi IL-1 $\alpha$, IL-1 $\beta$, dan IL-6. Ketiga mediator inflamasi ini menghambat pengeluaran orexin di bagian prefrontal cortex yang secara fisiologis memiliki fungsi untuk memperbaiki fungsi kognitif seseorang sehingga terjadi penurunan fungsi kognitif, penurunan konsentrasi, dan waktu reaksi seseorang lebih lama. ${ }^{10-14}$

Keterbatasan penelitian ini adalah faktor risiko yang dapat menyebabkan waktu reaksi menjadi lebih lambat tidak dapat dilakukan 
perbandingan secara statistik disebabkan oleh metodologi penelitian yang tidak sesuai dan jumlah peserta setiap kelompok faktor risiko tidak seimbang, tidak menghitung banyaknya kafein yang dikonsumsi oleh peserta PPDS selama melakukan tugas dan waktu peserta penelitian meminum kafein. Pada penelitian ini juga tidak mendokumentasikan waktu siklus menstruasi pada peserta PPDS wanita yang dapat memengaruhi waktu reaksi. Penelitian ini juga memiliki rentang usia peserta PPDS Anestesiologi yang pendek sehingga tidak dapat melihat korelasi usia dengan waktu reaksi.

\section{Simpulan}

Waktu reaksi yang dinilai secara visual terhadap peserta PPDS Anestesiologi dan Terapi Intensif RSUP Dr. Hasan Sadikin Bandung setelah bertugas selama 24 jam lebih lambat dibanding dengan sebelum bertugas selama 24 jam.

\section{Daftar Pustaka}

1. Gregory P, Edsell M. Fatigue and anaesthetist. Br J Anaesth. 2014;14(1):1822.

2. Sinha A, Singh A, Tewari A. The fatigued anesthesiologist. J Anaesthesiol Clin Pharmacol. 2013;29(2):151-7.

3. Saadat H, Bissonnette B, Tumin D, Raman V, Rice J, Barry N, dkk. Effects of partial sleep deprivation on reaction time in anesthesiologists. Paediatr Anaesth. 2017; 27(4):358-62.

4. Samatra P, Kesanda P, Andyana O, Widhyadarma E. The effect of partial sleep deprivation in decrease cognitive function in resident doctors of Udayana University/ Sanglah Hospital. IJSR. 2017;6(4):215-8.

5. Anitha V, Raj S. Reaction time sitting and standing posture among typical young adult. J Indian Assoc Physiother. 2018;12:58-62.

6. Yogi J, Hirkani M. Effect of sleep deprivation on audio-visual reaction times in resident doctors a measure of task performance.
IJBAMR. 2016;5(2):29-35.

7. Namita, Ranjan D, Shenvi D. A comparative study of auditory and visual reaction times in male and female staff during shift duty in hospital. J Evolution Med Dent Sci. 2010;21(2):199-203.

8. Jaffe D, Hewitt J, Comstock K, Bedard A. Effect of sleep deprivation on reaction: a mini review. COJ Tech Sci Res. 2016;1(1):15.

9. Kasozi K, Mbiydzneyuy N, Namubiru S, Safriyu S, Sulaiman S, Okpanachi A, dkk. A study visual, audio, and tactile reaction time among medical student at Kampala International University Uganda. Afri Health Sci. 2018;18(3):828-36.

10. Choudary AK, Kishanrao SS, Dhavinjay AKD, Alam T. Sleep restriction may lead to disruption in physiological attention and reaction time. Sleep Sci. 2016;9(3):20711.

11. Drummond, Brown G. The effect of total sleep deprivation on cerebral response to cognitive performance. EUR Neuropsychopharmacol. 2010;25:65-71.

12. Bobic T, Secic A, Zavoreo I, Matijevic V, Filipovic B, Kolak dkk. The impact sleep deprivation on brain. Acta Clin Croat. 2016;55(3):469-73.

13. Prabhavathi K, Hemamalini RV, Kumar T, Vallabadoss CA, Maruthy KN, Saravanan A, dkk. A correlation study of visual and auditory reaction time with their academic performance among the first medical student. Intern J Pharma India. 2017;7(4):371-4.

14. Ghuntla P, Metha H Gokhale P, Shah P. Influence of practice on visual reaction time. J Mahatma Gandhi Inst Med Sci. 2014;19:119-22.

15. Anitha V, Raj S. Reaction time sitting and standing posture among typical young adult. J Indian Assoc Physiother. 2018;12:58-62.

16. Nurchaeni A, Tavianto D, Oktaliansah E. Perubahan fungsi kognitif pada PPDS Anestesiologi dan Terapi Intensif Fakultas Kedokteran Universitas Padjadjaran setelah 24 jam kerja. JNI. 2019;3:160-7. 